DOI: https://doi.org/10.24127/ajpm.v10i3.3899

\title{
PENGEMBANGAN LEMBAR KERJA SISWA BERBASIS MIND MAPPING BERORIENTASI PADA HIGHER ORDER THINKING SKILLS
}

\author{
Reny Wahyuni ${ }^{1 *}$, Efuansyah ${ }^{2}$ \\ ${ }^{1 *, 2}$ STKIP PGRI Lubuklinggau, Lubuklinggau, Indonesia \\ ${ }^{*}$ Corresponding author \\ E-mail: $\quad{\frac{\text { renywahyuni264@gmail.com }}{\left.2{ }^{2}\right)}}^{\text {(1) }}$ \\ zxfe73@gmail.com $^{21}$
}

Received 02 July 2021; Received in revised form 13 September 2021; Accepted 24 September 2021

\begin{abstract}
Abstrak
Penelitian ini bertujuan untuk mengembangkan Lembar Kerja Siswa berbasis Mind Mapping berorientasi pada Higher Order Thinking Skills siswa kelas VIII yang valid dan praktis. Metode yang digunakan dalam penelitian ini adalah metode Research \& Development (R\&D). Adapun desain pengembangan Lembar Kerja Siswa ini menggunakan model pengembangan 4-D yaitu Tahap Pendefinisian (Define) yang terdiri dari analisis permasalahan, analisis peserta didik, analisis tugas, analisis konsep, dan analisis tujuan pembelajaran. Tahap Desain (Design) yang meliputi penyusunan instrumen, pemilihan format, dan rancangan awal produk. Tahap Pengembangan (Develop) terdiri dari validasi LKS, One to One, Small Group, dan Field Test. Tahap Penyebaran (Disseminate) pada tahap penyebaran ini LKS disebar dan diberikan guru matematika yang mengajar di kelas VIII dan Kepala Sekolah, serta guru kelas VII dan IX.. Dari hasil penelitian dan analisis data, maka didapatkan bahwa Lembar Kerja Siswa berbasis Mind Mapping berorientasi pada Higher Order Thinking Skills berada pada kategori Valid dengan skor rata-rata 3,92. Dimana untuk aspek tampilan diperoleh skor rata-rata sebesar 4,75 dan berada pada kategori sangat praktis, pada aspek penyajian materi diperoleh skor rata-rata sebesar 4,14 dan berada pada kategori praktis, sedangkan untuk aspek manfaat diperoleh skor rata-rata sebesar 4,21 dan berada pada kategoti praktis. Secara keseluruhan disimpulkan bahwa Lembar Kerja Siswa berbasis Mind Mapping berorientasi pada Higher Order Thinking Skills yang dikembangkan sangat praktis dengan skor rata-rata 4,37. Sehingga produk akhir yang dikembangkan dapat digunakan sebagai alternatif dalam pembelajaran matematika.
\end{abstract}

Kata kunci: HOTS, lembar kerja siswa, mind mapping, 4-D.

\begin{abstract}
This study aims to develop a Mind Mapping-based Student Worksheet oriented to the Higher Order Thinking Skills of class VIII students that is valid and practical. The method used in this research is the Research \& Development $(R \& D)$ method. The design for developing this Student Worksheet uses a 4-D development model, namely the Define Phase which consists of problem analysis, student analysis, task analysis, concept analysis, and analysis of learning objectives. The Design Phase which includes the preparation of instruments, the selection of formats, and the initial design of the product. Develop consists of LKS validation, One to One, Small Group, and Field Test. Disseminate. From the results of research and data analysis, it was found that the Mind Mapping-based Student Worksheet oriented to Higher Order Thinking Skills was in the Valid category with an average score of 3.92. Where for the display aspect, the average score is 4.75 and is in the very practical category, in the material presentation aspect, the average score is 4.14 and is in the practical category, while for the benefit aspect, the average score is 4,21 and is in the practical category. Overall, it was concluded that the Mind Mapping-based Student Worksheet was oriented towards Higher Order Thinking Skills which was developed very practically with an average score of 4.37. So that the final product developed can be used as an alternative in learning mathematics.
\end{abstract}

Keywords: HOTS, mind mapping, worksheet, 4-D

This is an open access article under the Creative Commons Attribution 4.0 International License 
DOI: https://doi.org/10.24127/ajpm.v10i3.3899

\section{PENDAHULUAN}

Matematika memiliki posisi yang cukup strategis dalam pendidikan sebagai sarana dalam mengembangkan daya pikir dan daya nalar peserta didik untuk mencapai tujuan yang ditetapkan (Chandra, 2019). Salah satu aspek matematika adalah mempunyai objek yang bersifat abstrak. Begitu juga kompleknya unsur-unsur yang ada dalam rumus matematika, banyaknya definisi penggunaan simbol-simbol yang bervariasi dan rumus-rumus yang beraneka ragam, menuntut peserta didik untuk lebih memusatkan pikirannya agar dapat menguasai konsep matematika tersebut (Sastrawati \& Novallyan, 2017). Sehingga perlu peranan penting pendidik khususnya guru untuk membantu peserta didik menvisualisasikan konteks nyata dari permasalahan abstrak dalam matematika. Kurikulum 2013 yang diterapkan sekarang dituntut agar pembelajaran mampu membimbing peserta didik dalam keterampilan berpikir tingkat tinggi (HOTS). HOTS (Higher Order Thinking Skill) adalah keterampilan yang lebih dari sekedar menghafalkan fakta atau konsep dengan mengharuskan peserta didik memahami, menganalisis, mengkategorikan, menciptakan cara dan menerapkannya dalam mencari solusi terhadap persoalan-persoalan (Riadi, 2016).

Tuntutan kurikulum 2013 dengan menjadikan peserta didik lebih kritis dan kreatif menjadikan sangat penting peran melatih keterampilan berpikir tingkat tinggi pada peserta didik dalam pembelajaran matematika yang terletak pada proses pembelajaran (Hidayati, 2017). Hal tersebut berhubungan dengan kurikulum 2013 yang memuat soal-soal matematika dengan tipe HOTS. Soal dengan tipe HOTS adalah soal yang menuntut kemampuan berpikir tingkat tinggi dan melibatkan proses bernalar, sehingga dapat mengasah kemampuan berpikir kritis, logis, reflektif, metakognitif dan kreatif. Pelajaran matematika diharapkan tidak hanya membekali peserta didik dengan kemampuan perhitungan rumus saja, namun mampu melibatkan keterampilan kritis dalam menyelesaikan soal bertipe HOTS. Seseorang dikatakan memiliki kemampuan berpikir kritis apabila peserta didik mampu memberikan jawaban yang bersifat reflektif, produktif dan evaluatif terhadap suatu permasalahan. Keterampilan berpikir kritis ini perlu dibiasakan dalam proses pembelajaran sehingga peserta didik memiliki kemampuan menyelesaikan permasalahan yang dihadapi (Haryanti, 2017). Keterampilan berpikir kritis dan kreatif dalam melihat, menganalisis dan memecahkan masalah menjadi bentuk keberhasilan yang dicapai oleh peserta didik dalam memahami konsep materi dan menguasai pengetahuan (Faelasofi, 2016). Hal ini sejalan dengan karakteristik skills masyarakat abad 21 yang dipublikasikan oleh Partnership of 21st Century Skill (Ismet, 2014) mengidentifikasikan bahwa pembelajar pada abad 21 harus mampu mengembangkan keterampilan kompetitif yang diperlukan pada abad 21 yang berfokus pada pengembangan Higher Order Thinking Skill. Sehingga sesuai dengan kurikulum 2013 tersebut diharapkan peserta didik dapat memanfaatkan pengetahuannya secara optimal agar lebih kritis serta kreatif dalam menerima dan mengolah informasi secara kreatif melalui metode pembelajaran yang tepat.

Pada hakikatnya, sumber belajar harus dimanfaatkan sesuai dengan fungsinya sendiri yaitu untuk menjadikan peserta didik lebih berpikir dan mampu menstimulus proses 
pembelajaran yang diajarkan oleh guru (Indriyani, 2019). Salah satu sumber belajar yang dapat digunakan di sekolah yaitu Lembar Kerja Siswa. Sesuai dengan tuntutan kurikulum 2013, Lembar Kerja Siswa seharusnya dapat mengakomodasi berbagai indikator kemampuan yang ada pada pembelajaran matematika, sehingga siswa tidak hanya mampu menyelesaikan berbagai soal matematika dalam soal rutin saja. Berdasarkan hasil observasi dan wawancara dengan guru Matematika di SMP Muhammadyah Jajaran Baru II, diperoleh informasi bahwa guru belum merancang sendiri LKS yang mampu mengakomodasi kebutuhan siswa untuk belajar lebih aktif. Belum adanya ketersediaan Lembar Kerja Siswa yang dapat memfasilitasi Higher Order Thinking Skills siswa menjadikan siswa tidak terbiasa dalam menyelesaikan soal-soal non rutin dan siswa menganggap pelajaran matematika sulit dipahami. Sumber belajar yang menarik bagi peserta didik dapat merangsang peserta didik dalam proses pembelajaran (Nurrita, 2018). Sehingga sumber belajar sangat penting bagi guru matematika dalam menyampaikan materi pelajaran kepada peserta didik, karena setiap pembelajaran tidak hanya teori yang disampaikan secara lisan namun juga dapat dilihat secara nyata oleh peserta didik selama proses belajar berlangsung.

Pemilihan metode pembelajaran matematika dapat membentuk karakter dari peserta didik tersebut. Mind Mapping (peta pikiran) merupakan metode yang tepat untuk memahami masalah dengan cara mencatat yang kreatif, efektif dan memetakan pikiran melalui gambar sederhana untuk memahami suatu konsep (Afrilianto, Rosyana, \& Senjawati, 2018). Metode Mind Mapping pun membantu otak manusia bekerja dengan baik dan tereksplor sesuai fungsinya (Faelasofi, 2016). Metode pembelajaran Mind Mapping diduga mampu membuat suasana pembelajaran yang menarik, motivasi peserta didik, dan menyenangkan ketika siswa mempelajari materi (Faelasofi, Arnidha, \& Istiani, 2015). Melalui Mind Mapping inilah dikonstruksikan untuk membimbing pemahaman konsep peserta didik terhadap materi bahasan berbasis HOTS sehingga membantu peserta didik sebagai pembaca menjadi senang, memahami bacaan dan melatih peserta didik menggunakan pikiran secara efektif. Salah satunya adalah dengan mengembangkan LKS sesuai dengan kebutuhan siswa (Agitsna, Wahyuni, \& Friansah, 2019).

Adapun penelitian terdahulu yang relevan dengan penelitian ini adalah (Purwasi \& Fitriyana, 2020) Pengembangan Lembar Kerja Peserta Didik (LKPD) Berbasis Higher Order Thinking Skills (HOTS) pada materi lingkaran dinyatakan valid dan praktis, serta hasil penilaian keefektifan melalui tes HOTS menunjukkan persentase ketuntasan secara klasikal sebesar $86,7 \%$ dan respon siswa menunjukkan respon positif terhadap LKPD. Selanjutnya (Noprinda \& Soleh, 2019) Pengembangan Lembar Kerja Peserta Didik (LKPD) Berbasis Higher Order Thinking Skills (HOTS), berdasarkan hasil validasi didapat persentase sebesar $85 \%$ dengan kriteria sangat baik dan uji coba didapat rata-rata persentase $90 \%$ dengan kriteria sangat baik, sehingga LKPD layak dan digunakan sebagai bahan ajar.

\section{METODE PENELITIAN}

Metode penelitian yang dipakai adalah metode Research \& Development (R\&D). Subjek penelitian 
DOI: https://doi.org/10.24127/ajpm.v10i3.3899

adalah siswa kelas VIII SMP Muhammadyah Jajaran Baru II. Adapun desain pengembangan Lembar Kerja Siswa ini menggunakan model pengembangan 4-D yang terdiri dari 4 tahap, yaitu pendefinisian (Define), desain (Design), pengembangan (Develop), penyebaran (Disseminate).

Tahap Pendefinisian, Tujuan dari tahap ini adalah menetapkan dan mendefinisikan kebutuhan yang dihadapi dalam pembelajaran Matematika. Tahap ini dilakukan melalui analisis permasalahan, analisis peserta didik, analisis tugas, analisis konsep, dan analisis tujuan pembelajaran. Tahap desain, tujuan dari tahap ini adalah menemukan cara yang lebih efektif dan efisien untuk mengembangkan rancangan produk awal (Draft I) berdasarkan data yang diperoleh pada tahap pendefinisian. Tahap pengembangan. Tujuan dari tahap ini adalah untuk menghasilkan Lembar Kerja Siswa berbasis Mind Mapping berorientasi pada Higher Order Thinking Skills yang sudah divalidasi dan direvisi berdasarkan masukan dari para pakar (ahli konten, konstruk dan bahasa) dan hasil uji coba ke siswa yang layak digunakan. Tahap penyebaran, pada tahap ini merupakan penggunaan LKS dalam skala yang lebih luas misalnya di kelas lain, guru lain, bahkan sekolah lain.

Instrumen yang digunakan dalam penelitian ini adalah lembar observasi, angket. Analisis lembar observasi dan angket. Angket validasi LKS dianalisis dengan mencari rata-rata penilaian antara penilai para pakar, baik ahli konten, isi, dan bahasa. Lembar penilaian LKS untuk ahli materi, media, dan bahasa diisi menggunakan Skala Likert dengan skor $1-5$. Setelah itu, menghitung rata-rata skor dari setiap komponen aspek penilaian. Selanjutnya, semua data yang sudah diperoleh pada tiap butir penilaian kemudian dijumlah untuk mengetahui kelayakan kualitas LKS yang dikembangkan berdasarkan Tabel 1.

Tabel 1. Kriteria Kevalidan LKS

\begin{tabular}{cc}
\hline Interval Rerata Skor & Kategori \\
\hline$x>4,21$ & Sangat Valid \\
$3,4<x \leq 4,21$ & Valid \\
$2,6<x \leq 3,4$ & Cukup Valid \\
$1,8<x \leq 2,6$ & Kurang Valid \\
$x \leq 1,8$ & Sangat Kurang \\
& Valid \\
\hline
\end{tabular}

Lembar penilaian kepraktisan LKS diberikan kepada siswa setelah siswa selesai melaksanakan pembelajaran menggunakan LKS untuk memfasilitasi kemampuan pemahaman konsep matematika. Analisis lembar penilaian kepraktisan siswa dilakukan berdasarkan langkah-langkah sebagai berikut : Merekapitulasi setiap item pernyataan lembar penilaian peserta didik terhadap LKS. Menentukan skor dari setiap butir pertanyaan dengan kriteria Skala Likert 1-5. Selanjutnya rata-rata kepraktisan disesuaikan dengan Tabel 2.

Tabel 2. Kriteria Kepraktisan LKS

\begin{tabular}{cc}
\hline Interval Rerata Skor & Kategori \\
\hline$x>4,21$ & Sangat Praktis \\
$3,4<x \leq 4,21$ & Praktis \\
$2,6<x \leq 3,4$ & Cukup Praktis \\
$1,8<x \leq 2,6$ & Kurang Praktis \\
$x \leq 1,8$ & Sangat Kurang \\
& Praktis \\
\hline
\end{tabular}

\section{HASIL DAN PEMBAHASAN}

Pengembangan lembar kerja siswa berbasis mind mapping berorientasi higher order thinking skills ini menggunakan model 4-D, tahapan prosedur yang dilakukan dengan menggunakan model 4-D meliputi 4 tahap, yaitu Define, Design, Development, dan Disseminate. 
DOI: https://doi.org/10.24127/ajpm.v10i3.3899

\section{Define}

Adapun hasil analisis pada tahap ini adalah: Hasil dari analisis permasalahan, maka ditemukan bahwa siswa tidak terbiasa menjawab soal-soal non rutin yang membutuhkan tingkat pemikiran lebih tinggi. Analisis karakteristik peserta didik dilakukan dengan mengidentifikasi karakter siswa yang akan menggunakan LKS. Berdasarkan hasil observasi yang dilakukan, maka didapat rata-rata umur siswa kelas VIII SMP Muhammadyah Jajaran Baru II berkisar antara umur 1214 tahun. Pada usia itu anak sudah dapat berpikir secara abstrak, namun tetap dibimbing dan diarahkan agar kemampuan berpikir abstraknya dapat terus terasah. Sehingga anak terbiasa dengan pola pikir yang lebih rumit dan terbiasa dalam menyelesaikan permasalahan HOTS, dimana soal dengan tipe HOTS adalah soal yang menuntut kemampuan berpikir tingkat tinggi dan melibatkan proses bernalar, sehingga dapat mengasah kemampuan berpikir kritis, logis, reflektif, metakognitif dan kreatif (Suryapuspitarini, 2018). Berdasarkan kurikulum 2013, maka materi yang diambil adalah Bangun Ruang Sisi Datar dengan Kompetensi Dasar 3.9. Menentukan luas permukaan dan volume kubus, balok, prisma, dan limas. Hasil dari analisis konsep adalah siswa harus mampu menguasai konsep bangun ruang sisi datar dengan sub pokok bahasan luas permukaan kubus, volume kubus, luas permukaan balok, volume balok, permasalahan yang berhubungan dengan kehidupan sehari-hari. Analisis tujuan pembelajaran bertujuan agar peserta didik setelah melakukan pembelajaran menggunakan LKS dapat mencapai kompetensi yang telah ditentukan.

\section{Design}

Tahapan ini meliputi: penyusunan instrumen, pemilihan format, dan rancangan awal produk.

a. Penyusunan Instrumen

Pembuatan instrumen penilaian kevalidan LKS mengacu pada kriteria LKS yang baik menurut Badan Standar Nasional Pendidikan (BSNP). Instrumen ini terdiri dari tiga macam, yaitu : penilaian LKS oleh ahli materi, ahli bahasa dan ahli media. Ketiga instrumen tersebut menggunakan skala Likert dengan 5 alternatif jawaban yang masing-masing menunjukkan penilaian Sangat Baik - Sangat Kurang. Instrumen tersebut digunakan untuk menilai kualitas LKS yang dikembangkan berdasarkan komponen kelayakan isi, kelayakan penyajian, penilaian Higher Thinking Skills, kelayakan bahasa, dan kelayakan kegrafikan. Validasi Materi, pada lembar instrumen penilaian LKS untuk validasi materi terdiri dari 25 butir pertanyaan. Validasi Bahasa, instrumen penilaian untuk validasi bahasa terdiri dari 11 butir pernyataan yang terdiri dari 5 aspek penilaian. Validasi Media, instrumen penilaian untuk validasi media terdiri dari 25 butir pernyataan yang terdiri dari 3 aspek penilaian. Instrumen penilaian kepraktisan LKS terdiri dari 21 butir pernyataan yang terbagi menjadi 3 aspek penilaian yaitu aspek tampilan, penyajian materi dan manfaat.

\section{b. Pemilihan Format}

Menyusun peta kebutuhan, hasil dari menyusun peta kebutuhan dapat memberikan keterangan tentang banyaknya LKS yang harus dibuat. Menyusun Kerangka LKS, LKS yang dikembangkan terdiri 3 bagian, yaitu bagian awal, bagian isi, dan bagian akhir. Bagian awal LKS terdiri dari cover LKS, identitas LKS, kata 
pengantar, petunjuk penyajian LKS, Mind Mapping, dan daftar isi. Bagian isi, pada bagian ini didahului dengan kompetensi inti, kompetensi dasar, dan aktivitas kegiatan siswa dalam memahami materi bangun ruang sisi datar, penyelesaian soal berdasarkan aktivitas yang telah dilakukan siswa, permasalahan yang berkaitan dengan kehidupan sehari-hari siswa yang berhubungan dengan materi bangun ruang sisi datar dan latihan-latihan soal individu per sub pokok bahasan, dan diakhiri dengan soal-soal uji kompetensi untuk melatih kemampuan siswa. Pada bagian akhir terdapat daftar pustaka dan halaman sampul belakang. LKS yang dikembangkan dapat membantu siswa dalam memahami materi, karena proses belajar matematika sangat memerlukan media yang mudah dimengerti oleh peserta didik (Octavianingrum, 2016).

\section{c. Rancangan Awal}

LKS yang dikembangkan menggunakan Bahasa Indonesia dan disusun berdasarkan pada tahapan sebelumnya. Adapun rancangan awal LKS ini dapat dilihat pada Gambar 1.

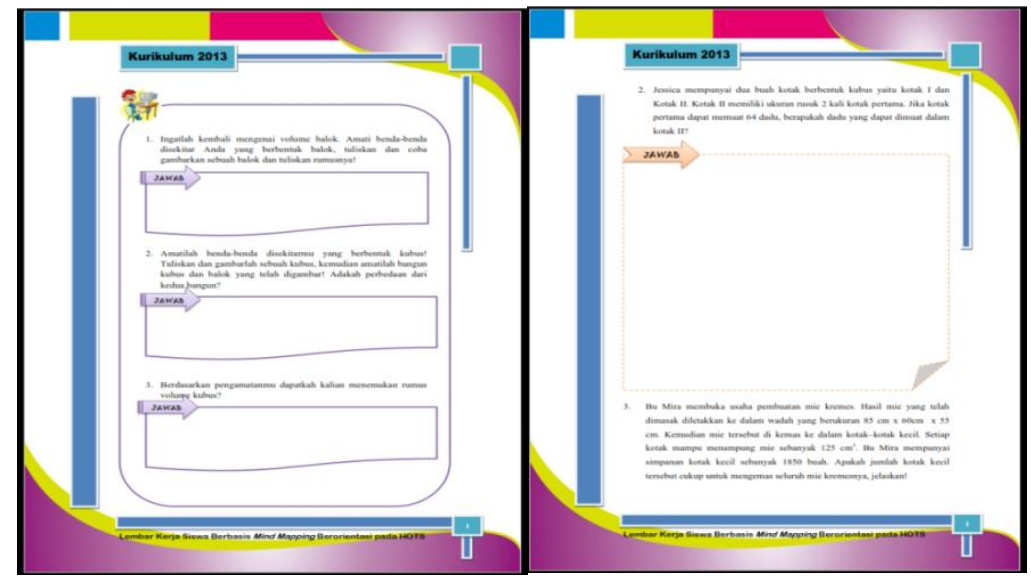

Gambar 1. Desain rancangan awal LKS

\section{Development}

Validasi LKS

Validasi dilakukan kepada 3 validator, yaitu validasi materi oleh Rani Refianti, M.Pd., validasi bahasa oleh Agung Nugroho, M.Pd. dan validasi media oleh Dr. Dodik Mulyono, M.Pd.,. Pada proses validasi ini ketiga validator memberikan komentar dan saran untuk perbaikan LKS, selanjutnya hasil penilaian dan saran dari validator digunakan untuk revisi LKS pada tahap selanjutnya. Berdasarkan keseluruhan penilaian yang telah dilakukan terhadap 3 orang ahli terhadap LKS yang telah diuraikan di atas menunjukkan bahwa LKS yang dikembangkan berada pada kategori valid dengan skor rata-rata keseluruhan sebesar 3,92 berada pada kategori valid seperti yang telihat pada Tabel 2 .

Tabel 2. Rekapitulasi Penilaian

\begin{tabular}{cccccc}
\hline No & Validator & Jumlah Butir & Skor & Skor rata-rata & Kategori \\
\hline 1 & Materi & 25 & 94 & 3,76 & Valid \\
2 & Media & 25 & 100 & 4,00 & Valid \\
3 & Bahasa & 11 & 44 & 4,00 & Valid \\
\hline & Total & 61 & 238 & 3,92 & Valid \\
\hline
\end{tabular}


DOI: https://doi.org/10.24127/ajpm.v10i3.3899

\section{One to One}

Tahap One to One dilakukan kepada 3 siswa dengan kemampuan yang heterogen, dimana siswa tersebut diminta untuk menggunakan LKS yang telah dibuat dan guru mengobservasi kesulitan apa saja yang dihadapi oleh siswa selama menggunakan LKS tersebut. Semakin abstrak konsep dalam matematika maka akan semakin menyulitkan peserta didik dalam memahami konsep tersebut (Sanusi, Suprapto, \& Apriandi, 2015), sehingga LKS yang dikembangkan dekat dengan kehidupan sehari-hari siswa.

Guru juga melakukan wawancara kepada siswa untuk mengetahui tingkat pemahaman siswa selama menggunakan LKS. LKS direvisi sesuai dengan komentar dan saran dari ketiga validator dan siswa pada tahap one to one, sehingga LKS 1 yang telah direvisi menjadi LKS 2. Pada LKS 2 telah didapatkan bahwa LKS tersebut Valid dengan skor rata-rata sebesar 3,92.

\section{Small Group}

Uji coba kelompok kecil dilakukan terhadap 6 orang siswa dengan tingkat kemampuan yang berbeda, yaitu kemampuan tinggi, kemampuan sedang dan kemampuan rendah. Siswa diminta untuk mengerjakan LKS yang telah dibuat, dari hasil pekerjaan mereka terlihat bahwa siswa tersebut dapat menggunakan LKS dengan baik. Setelah tahap uji coba kelompok kecil dilaksanakan, maka selanjutnya LKS dievaluasi dan direvisi sesuai dengan saran dan komentar pada saat uji coba kelompok kecil.

\section{Field Test}

Setelah melakukan uji coba kelompok kecil, maka tahapan selanjutnya adalah tahap field test pada kelas sesungguhnya. Uji coba LKS dilaksanakan di kelas VIII SMP Muhammadyah Jajaran Baru II sebanyak 3 kali pertemuan dengan durasi 2 x 40 menit. Setelah siswa selesai mengikuti proses pembelajaran menggunakan LKS yang berorientasi pada Higher Order Thinking Skills, siswa diminta untuk mengisi lembar penilaian kepraktisan penggunaan LKS terhadap LKS yang dikembangkan. Angket penilaian kepraktisan LKS untuk siswa terdiri dari 21 butir pernyataan, yang terdiri dari aspek tampilan, penyajian materi, dan manfaat penggunaan LKS. Selanjutnya, lembar tersebut dianalisis dan analisis lembar penilaian tersebut untuk mengetahui kepraktisan LKS yang dikembangkan. hasil dari analisis uji kepraktisan dapat dilihat pada Tabel 4.

Tabel 4. Hasil Analisis Kepraktisan

\begin{tabular}{cccc}
\hline No & Aspek & $\begin{array}{c}\text { Skor Rata- } \\
\text { Rata }\end{array}$ & Kategori \\
\hline 1 & Tampilan & 4,75 & $\begin{array}{l}\text { Sangat } \\
\text { Praktis }\end{array}$ \\
2 & $\begin{array}{l}\text { Penyajian } \\
\text { Materi }\end{array}$ & 4,14 & Praktis \\
3 & Manfaat & 4,21 & Praktis \\
\hline \multirow{2}{*}{ Total } & 4,37 & $\begin{array}{l}\text { Sangat } \\
\text { Praktis }\end{array}$ \\
\hline
\end{tabular}

Berdasarkan hasil analisis lembar penilaian kepraktisan, diperoleh skor rata-rata sebesar 4,37 dan berada pada kategori Sangat Praktis. Berdasarkan hasil perhitungan menunjukkan penilaian positif terhadap LKS yang berorientasi Higher Order Thinking Skills. Peserta didik yang memiliki kemampuan Higher Order Thinking Skills tidak akan kesulitan dalam memahami materi pelajaran matematika (Ginanjar, 2019). Hal ini sesuai tuntutan kurikulum 2013 dengan menjadikan peserta didik lebih kritis dan kreatif menjadikan sangat penting peran 
melatih keterampilan berpikir tingkat tinggi pada peserta didik dalam pembelajaran matematika yang terletak pada proses pembelajaran (Hidayati, 2017).

Sedangkan komentar siswa pada tahap ini tidak terlalu banyak, untuk keseluruhan LKS siswa dapat memahami dan menggunakan LKS dengan baik, sehingga siswa dapat memahami materi bangun ruang sisi datar dengan mudah, tanpa adanya kesulitan yang mendalam. Melalui LKS yang berbasis Mind Mapping dapat membuat siswa lebih mudah memahami materi pelajaran dengan baik, hal ini dikarenakan Mind Mapping merupakan metode yang tepat untuk memahami masalah dengan cara mencatat yang kreatif, efektif dan memetakan pikiran melalui gambar sederhana untuk memahami suatu konsep (Afrilianto, Rosyana, \& Senjawati, 2018). Metode Mind Mapping pun membantu otak manusia bekerja dengan baik dan tereksplor sesuai fungsinya (Faelasofi, 2016).

\section{Disseminate}

Tahap terakhir dari proses pengembangan LKS berbasis Mind Mapping berorientasi pada Higher Order Thinking Skills adalah tahap penyebaran LKS. Setelah LKS direvisi sesuai dengan saran dan komentar dari para validator dan dianalisis tingkat kevalidan dan kepraktisan LKS, sehingga LKS tersebut dapat digunakan di kelas dan pada guru lain sesuai dengan bidang studi yang diajarkan. SMP Muhammadyah Jajaran Baru II Kabupaten Musi Rawas terdiri dari 3 kelas dan ada 3 guru matematika yang mengajar, sehingga pada tahap penyebaran ini LKS disebar dan diberikan guru matematika yang mengajar di kelas VIII dan Kepala Sekolah, serta guru kelasVII dan IX.
Berdasarkan hasil yang diperoleh, penelitian ini sejalan dengan penelitian (Purwasi \& Fitriyana, 2020) dimana LKPD yang dikembangkan berbasis Higher Order Thinking Skills menunjukkan hasil penilaian keefektifan HOTS secara klasikal sebesar $86,7 \%$ dengan respon positif dari siswa. Selain itu, penelitian ini juga sejalan dengan penelitian yang dilakukan oleh (Noprinda \& Soleh, 2019) berdasarkan hasil validasi didapat persentase sebesar $85 \%$ dengan kriteria sangat baik dan uji coba didapat rata-rata persentase $90 \%$ dengan kriteria sangat baik, sehingga LKPD layak dan digunakan sebagai bahan ajar.

LKS yang telah dikembangkan memiliki implikasi hasil penelitian, produk LKS ini dapat digunakan sebagai salah satu referensi pembelajaran matematika bagi guru dan siswa untuk memfasilitasi kemampuan berpikir tingkat tinggi. Sehingga LKS ini dapat digunakan sebagai pelengkap dari buku paket yang telah ada. Selanjutnya LKS yang telah dikembangkan dapat menjadi bahan bagi siswa dalam memahami pelajaran matematika dengan mudah karena pada LKS materi pembelajaran dibantu menggunakan Mind Maping yang mudah dipelajari siswa.

\section{KESIMPULAN DAN SARAN}

Hasil dari penelitian dan pengembangan yang telah dilakukan, menghasilkan Lembar Kerja Siswa Berbasis Mind Mapping berorientasi pada Higher Order Thinking Skills didapatkan bahwa LKS tersebut Valid dan Sangat Praktis. Sehingga penggunaan LKS ini dapat menjadi alternatif pembelajaran di sekolah untuk memfasilitasi kemampuan berpikir tingkat tinggi siswa kelas VIII terutama pada materi bangun ruang sisi datar. 
Penelitian ini hanya sebatas melihat aspek kevalidan dan kepraktisan dari penggunaan LKS, oleh karena itu diharapkan ada penelitian lebih lanjut untuk mengembangkan LKS ini pada materi yang lebih luas dan penyebarannya lebih luas lagi, sehingga penggunaan LKS ini dapat dirasakan oleh masyarakat secara luas.

\section{DAFTAR PUSTAKA}

Afrilianto, M., Rosyana, T., \& Senjawati, E. (2018). Strategi Formulate-Share-Listen-Create untuk Meningkatkan Kemampuan Masalah Matematika Siswa SMK dan Disposisi Matematika pada Konsep Probabilitas. Infinity : Journal of Mathematics Education, 7(1), 1-6.

Agitsna, L. D., Wahyuni, R., \& Friansah, D. (2019). Pengembangan Lembar Kerja Siswa Berbasis Problem Based Learning pada Materi Bangun Ruang Sisi Datar. AKSIOMA : Jurnal Program Studi Pendidikan Matematika, 8(3), 429-437.

Chandra, F. E. (2019). Penerapan Sistem Pendidikan Pramuka dalam Pembelajaran Matematika Guna Meningkatkan Disposisi Matematika Siswa. Axioma : Jurnal Program Studi Pendidikan Matematika Universitas Islam Jember, 4(1), 16-26.

Faelasofi, R. (2016). Penerapan Metode Mind Mapping pada Pembelajaran Matematika. Jurnal e-DuMath, 2(2), 185-192.

Faelasofi, R., Arnidha, Y., \& Istiani, A. (2015). Metode Pembelajaran Mind Mapping untuk Meningkatkan Kemampuan Komunikasi Matematika Siswa dalam Pemecahan Masalah
Matematika. Jurnal e-DuMath, 1(2), 122-136.

Ginanjar, A. Y. (2019). Pentingnya Penguasaan Konsep Matematika dalam Pemecahan Masalah Matematika di SD. Jurnal Pendidikan Universitas Garut, 13(1), 17-25.

Haryanti, Y. D. (2017). Model PBL Membangun Kemampuan Berpikir Kritis Siswa Sekolah Dasar. Jurnal Cakrawala Pendas, 3(2), 57-63.

Hidayati, A. U. (2017). Melatih Kemampuan Berpikir Tingkat Tinggi dalam Pembelajaran Matematika pada Siswa Sekolah Dasar. Jurnal Pendidikan dan Pembelajaran Dasar, 4(2), 143156.

Ismet, B. (2014). Assesment Pembelajaran. Bandung: PT. Remaja Rosdakarya.

Indriyani, L. (2019). Pemanfaatan Media Pembelajaran dalam Proses Belajar untuk Meningkatkan Kemampuan Berpikir Kognitif Siswa. Prosiding Seminar Nasional Pendidikan (pp. 17-26). Serang: Universitas Sultan Ageng Tirtayasa.

Noprinda, C. T., \& Soleh, S. M. (2019). Pengembangan Lembar Kerja Peserta Didik (LKPD) Berbasis Higher Order Thinking Skills (HOTS). Indonesian Journal of Science and Mathematics Education, 2(2), 168-176.

Nurrita, T. (2018). Pengembangan Media Pembelajaran untuk Meningkatkan Hasil Belajar Siswa. Jurnal Misyikat, 3(1), 171187.

Octavianingrum, D. (2016). Pengembangan Media Audio Visual Sparkol Dalam Pembelajaran Mengelola Rapat 
DOI: https://doi.org/10.24127/ajpm.v10i3.3899

Pertemuan Di LPP IPMI Kusuma

Bangsa Surakarta. Jurnal

Perpustakaan UNS , 1-14.

Purwasi, L. A., \& Fitriyana, N. (2020). Pengembangan Lembar Kerja Peserta Didik (LKPD) Berbasis Higher Order Thinking Skills (HOTS). AKSIOMA : Jurnal Program Studi Pendidikan Matematika, 9(4), 894-908.

Riadi, A. (2016). Problem Based Learning Meningkatkan Higher Order Thinking Skill Siswa Kelas VIII SMPN 1 dan SMPN 2 Daha Utara. Math Didactic : Jurnal Pendidikan Matematika, 2(3), 154-163.

Sanusi, Suprapto, E., \& Apriandi, D. (2015). Pengembangan Multimedia Interaktif Sebagai Media Pembelajaran pada Pokok Bahasan Dimensi Tiga di Sekolah Menengah Atas (SMA). Jurnal Ilmiah Pendidikan Matematika, 3(2), 398-416.

Sastrawati, E., \& Novallyan, D. (2017). Pengembangan Media Pembelajaran Interaktif Berbasis Android untuk Pemahaman Konsep Trigonometri. IEJR (Jurnal Riset Pendidikan Indonesia), 2(2), 72-76.

Suryapuspitarini, B. K. (2018). Analisis Soal-Soal Matematika Tipe Higher Order Thinking Skill (HOTS) pada Kurikulum 2013 untuk Mendukung Kemampuan Literasi Siswa. PRISMA: Prosiding Seminar Nasional Matematika (hal. 876-881). 20 Oktober 2018. 